\title{
Variabilidade de progênies F2 de amendoim geradas por meio de seleção de genitores ISSR-divergentes ${ }^{1}$
}

\author{
Variability of $\mathrm{F}_{2}$ peanut progenies generated through the selection of ISSR-divergent \\ genitors
}

\author{
Roseane Cavalcanti dos Santos ${ }^{2 *}$, Camila Marques Queiroz ${ }^{3}$, Vandré Guevara Lyra Batista ${ }^{4}$, Carliane Rebeca \\ Coelho Silva ${ }^{5}$, Morganna Pollynne Nóbrega Pinheiro ${ }^{5}$, Antônio Lopes de Arroxelas Galvão Filho², Péricles de \\ Albuquerque Melo Filho6 e Liziane Maria de Lima²
}

\begin{abstract}
RESUMO - Marcadores ISSR foram utilizados para discriminar acessos intraespecíficos de amendoim e utilizar os mais divergentes para geração de variabilidade por meio de cruzamentos. Os acessos foram cultivados em casa de vegetação e aos 20 dias após o plantio foram coletadas folhas para extração de DNA e posterior ensaios de PCR-ISSR. Dez primers foram utilizados gerando bandas mono e polimórficas. Dentre eles, os mais responsivos em termos de discriminação dos acessos foram UBC-818 e UBC-842, que geraram, respectivamente, 14 e 12 bandas e taxa de polimorfismo de 64 e $83 \%$. Os primers UBC-847 e UBC-858 geraram poucas bandas e mais de $60 \%$ foram monomórficas, de pouco valor para estudos de discriminação de acessos por meio de marcadores do tipo ISSR. Três grupos distintos foram formados no dendrograma, entre os quais, dois genótipos de maior divergência, representados pela cultivar BR 1 (precoce, de porte ereto) e a linhagem LViPE-06 (tardio e rasteiro), foram selecionados para os trabalhos de hibridação para gerar variabilidade genética. As progênies $F_{2}$ resultantes apresentaram larga variabilidade genética, de grande contribuição para os trabalhos de seleção no melhoramento do amendoim. Com base nos resultados obtidos, foi possível confirmar a contribuição das ferramentas moleculares como auxiliar nos trabalhos de seleção de amendoim.
\end{abstract}

Palavras-chave: Amendoim-melhoramento genético. Hibridação vegetal.

\begin{abstract}
ISSR markers were used to discriminate intraspecific peanut accessions, and to utilize the most divergents aiming to generate variability by crossing. The accessions were grown in a greenhouse and at 20 days after sowing, leaves were collected for DNA extraction and subsequent ISSR-PCR tests. Ten primers were used to generate mono and polymorphic bands. Among them, the most contributive to discriminating accessions were UBC-818 and UBC-842, which respectively produced 14 and 12 bands, and a polymorphism rate of 64 and $83 \%$. The primers UBC- 847 and UBC- 858 generated few bands, with over $60 \%$ monomorphic and low contribution to studies of access discrimination using ISSR markers. Three distinct clusters were formed in the dendrogram, among which two genotypes with greater divergence, represented by cultivar BR 1 (short cycle and upright) and line LViPE-06 (late cycle and runner), were selected for hybridization to generate genetic variability. The resulting $\mathrm{F}_{2}$ progenies showed broad genetic variability, with large contribution to selection procedures for the to assist selection procedures in peanut. Based on the results obtained, it was possible to confirm the contribution of molecular tools to assist selection procedures in peanut.
\end{abstract}

Key words: Peanut-breeding. Hybridization.

\footnotetext{
*Autor para correspondência

${ }^{1}$ Recebido para publicação em 19/10/2010; aprovado em 31/01/2013

Pesquisa financiada pelo Banco do Nordeste do Brasil

${ }^{2}$ Laboratório de Biotecnologia/Embrapa Algodão, Caixa Postal 174, Campina Grande-PB, Brasil, 58.428-095, roseane.santos@embrapa.br, arroxelas@cnpa.embrapa.br,liziane.lima@embrapa.br

${ }^{3}$ Departamento de Ciências Biológicas/UEPB, Campina Grande-PB, Brasil, cmilacg@ hotmail.com

${ }^{4}$ Programa de Pós-Graduação em Ciências Agrárias/UEPB, Campina Grande-PB, Brasil, vanguevara@gmail.com

${ }_{5}^{5}$ Departamento de Pós-Graduação em Biotecnologia/Rede Nordeste de Biotecnologia/RENORBIO/UECE, Fortaleza-CE, Brasil, carliane. rebeca@gmail.com, morgannapollynne@yahoo.com.br

${ }^{6}$ Departamento de Agronomia/UFRPE, Recife-PE, Brasil, pericles@ depa.ufrpe.br
} 


\section{INTRODUÇÃO}

O amendoim (Arachis hypogaea L.) é uma oleaginosa de grande valor econômico, com uma produção superior a 31 milhões de toneladas em grãos e 6 milhões de toneladas em óleo, liderada pelos principais produtores mundiais: China, Índia e EUA (FOOD AND AGRICULTURE ORGANIZATION, 2010; UNITED STATES DEPARTMENT OF AGRICULTURE, 2010). No Brasil, a produção da lavoura tem se situado em 345 mil toneladas de amendoim em vagens, oriunda das regiões Sul, Sudeste, Centro-Oeste e Nordeste (INSTITUTO BRASILEIRO DE GEOGRAFIA E ESTATÍSTICA, 2012).

As variedades comerciais disponíveis no mercado são representadas por duas subespécies, hypogaea e fastigiata, que distinguem entre si, basicamente, quanto ao hábito de crescimento, ciclo, tamanho da semente e presença de flor na haste principal (VALLS, 2005). A subespécie hypogeae engloba as variedades do grupo Virgínia (hábito de crescimento rasteiro ou runner), enquanto que na fastigiata encontram-se as variedades do grupo Valência (hábito de crescimento ereto).

Nos trabalhos de melhoramento que envolvem caracterização de germoplasma, a discriminação de acessos de amendoim baseia-se, especialmente, em atributos capazes de serem identificados por meio de descritores fenotípicos. Como a planta é de natureza autógama e as flores possuem alto nível de cleistogamia, a detecção de variabilidade intraespecífica torna-se limitada devido a alta uniformidade genética dos acessos. Como consequência, o sucesso na escolha de genótipos para servirem como genitores em trabalhos de cruzamentos torna-se restrito em função de não se poder prever o nível de variabilidade requerida para avançar nos processos de seleção. Por outro lado, como a maioria das cultivares comerciais tem base genética estreita, o êxito na seleção de populações segregantes delas derivadas é reduzido drasticamente implicando em menor progresso no melhoramento da cultura.

Vários melhoristas tem adotado as ferramentas de marcadores moleculares para auxiliar nos trabalhos de melhoramento, em especial para caracterização de germoplasma, seleção assistida, identificação de acessos com tolerância a estresses bióticos e abióticos, etc, cujos resultados têm contribuído no avanço dos trabalhos de melhoramento de várias culturas, como soja (MENG; CHEN, 2001), feijão (RODRIGUES et al., 2007), milho (BARAKAT; EL-SHAFEI; AL-DOSS, 2010), algodão (HAWKINS; PLEASANTS; WENDEL, 2005), entre outras. Entre os marcadores que permitem distinguir acessos com maior precisão e confiabilidade citam-se os dos tipos ISSR (Inter Simple Sequence Repeat), RFLP (Restriction Fragment Length Polymorphism), AFLP (Amplified Fragment Length Polymorphism), SSR (Simple
Sequence Repeats or microsatellite) e VNTR (Variable Number of Tandem Repeats) (BARAKAT; EL-SHAFEI; AL-DOSS, 2010; FERREIRA; GRATTAPAGLIA, 1998; RODRIGUES et al., 2007).

Os marcadores ISSR têm sido amplamente utilizados pelos melhoristas de plantas porque, além das vantagens acima reportadas, é de fácil operação, não exige uso de enzimas de restrição e são de grande utilidade nos estudos que visam determinar a distância genética entre parentais e o desempenho dos híbridos para construção de mapas genéticos de ligação.

Neste trabalho, avaliou-se a variabilidade adquirida em progênies F2, geradas a partir de genótipos divergentes selecionados via PCR-ISSR.

\section{MATERIAL E MÉTODOS}

Onze acessos intraespecíficos de amendoim, pertencentes às subespécies hypogeae e fastigiata, foram selecionados para a análise de divergência, baseandose em descritores agronômicos e físico-químicos previamente definidos pela equipe de melhoramento genético de amendoim da Embrapa Algodão. Uma síntese dos principais descritores encontra-se na Tabela 1.

Sementes de cada um dos acessos foram cultivadas na casa de vegetação da área de Biotecnologia da Embrapa Algodão, em Campina Grande, PB. As plantas foram utilizadas para extração de DNA e posterior uso das flores nos trabalhos de cruzamentos.

Os ensaios moleculares foram conduzidos no Laboratório de Biotecnologia da Embrapa Algodão. O DNA de cada material foi extraído a partir de folhas jovens seguindo metodologia descrita em Santos e Santos (2008). Após extração, todas as amostras foram aliquotadas em $20 \mathrm{ng} / \mu \mathrm{l}$ para os ensaios de PCR.

As reações de PCR-ISSR foram conduzidas em um volume final de $25 \mu \mathrm{L}$ contendo: $0,3 \mu \mathrm{L}$ de Taq DNA polimerase (Fermentas, $5 \mathrm{U} / \mu \mathrm{L}$ ), 2,5 $\mu \mathrm{L}$ de tampão da enzima (10 X), 1,4 $\mu \mathrm{L}$ de $\mathrm{MgCl}_{2}(25 \mathrm{mM}), 0,5 \mu \mathrm{L}$ de dNTP $(10 \mathrm{mM}), 1 \mu \mathrm{L}$ de cada primer ISSR $(10 \mu \mathrm{M})$ e $1 \mu \mathrm{L}$ de cada DNA genômico (20 ng/ $\mu \mathrm{L})$. Dez primers ISSR, desenvolvidos pelo Laboratório de Biotecnologia da Universidade da Columbia Britânica (UCB), foram utilizados para o estudo (Tabela 2). As reações consistiram de uma desnaturação inicial a $94^{\circ} \mathrm{C} / 4 \mathrm{~min}$, seguido por 35 ciclos de 1 min de desnaturação a $94{ }^{\circ} \mathrm{C}, 1$ min de anelamento a $45{ }^{\circ} \mathrm{C}$ e 1 min de extensão a $72{ }^{\circ} \mathrm{C}$, e finalmente, um ciclo de extensão a $72{ }^{\circ} \mathrm{C} / 7 \mathrm{~min}$. Os produtos da amplificação foram corados com Syber Green (LGC) em gel de agarose $(1,2 \%)$ e fotodocumentados. 
Tabela 1 - Descritores morfológicos e agronômicos dos acessos utilizados neste trabalho

\begin{tabular}{lcccccccc}
\hline \multicolumn{1}{c}{ Acesso } & HB & CS & Sp & SV & Ciclo & TES & TS & O $(\%)$ \\
\hline LGoPE-06 & R & B & h & $1-2$ & $130-135$ & Não & EG & 51 \\
CNPA 271 AM & E & V & f & $1-2$ & $90-100$ & Sim & M & 48 \\
BRS Havana & E & B & f & $3-4$ & $85-90$ & Sim & M & 43 \\
BR 1 & E & V & f & $3-4$ & $87-90$ & Sim & M & 45 \\
CNPA 283 AM & E & B & f & $1-2$ & $90-100$ & Sim & M & 48 \\
LViPE-06 & R & B & h & $1-2$ & $120-125$ & Sim & EG & 51 \\
CNPA 270 AM & E & V & f & $1-2$ & $90-100$ & Sim & M & 45 \\
CNPA 280 AM & E & B & f & $1-2$ & $90-100$ & Sim & M & 46 \\
IAC Caiapó & R & B & h & $1-2$ & $130-135$ & Não & G & 49 \\
Florunner & R & B & h & $1-2$ & $120-130$ & Não & G & 49 \\
L 7 Bege & E & B & f & $1-2$ & $90-95$ & Sim & M & 45 \\
\hline
\end{tabular}

Legenda: HB- hábito de crescimento: E- ereto, R- rasteiro; CS- cor da semente: V- vermelha, B- bege; Sp- subespécie: h- hypogaea, f- fastigiata; SV- semente/ vagem; TES- tolerância ao estresse hídrico; TS- tamanho da semente: M- média, G- grande, EG- extra grande; O- teor médio de óleo nas sementes

Tabela 2 - Relação dos primers, desenvolvidos pela Universidade da Columbia Britânica, utilizados com os genótipos intraespecíficos de amendoim

\begin{tabular}{|c|c|}
\hline Primers & Sequências \\
\hline UCB-812 & GAGAGAGAGAGAGAGAA \\
\hline UCB-816 & CACACACACACACACAT \\
\hline UCB-817 & CACACACACACACACAA \\
\hline UCB-818 & CACACACACACACACAG \\
\hline UCB-809 & AGAGAGAGAGAGAGAGG \\
\hline UCB-836 & AGAGAGAGAGAGAGAGYA \\
\hline $\mathrm{UCB}-842$ & GAGAGAGAGAGAGAGAYG \\
\hline UCB-847 & CACACACACACACACARC \\
\hline UCB-815 & СТСТСТСТСТСТСТстG \\
\hline UCB-858 & TGTGTGTGTGTGTGTGRT \\
\hline
\end{tabular}

Bases degeneradas: $\mathrm{Y}=\mathrm{C}, \mathrm{T} ; \mathrm{R}=\mathrm{A}, \mathrm{G}$

Para análise genética, os produtos da amplificação foram codificados adotando-se metodologia usual, atribuindo presença (1) ou ausência (0) da banda, para cada acesso, registrando-se apenas bandas nítidas no gel. Uma matriz de dados binários foi gerada, a partir da qual, foi calculado o índice de similaridade genética entre todos os indivíduos, comparados dois a dois, utilizando-se o índice de concordância de Jaccard (SNEATH; SOKAL, 1973).

As similaridades obtidas (Sji) foram calculadas, segundo a expressão 1:

$$
S j i=\frac{a}{a+b+c}
$$

onde a significa a presença de bandas em ambos os acessos; b a presença de banda no primeiro acesso e ausência no segundo e c, presença no segundo e ausência no primeiro.

Para obtenção da matriz de similaridade genética e construção do dendrograma empregou-se o programa NTSYSpc 2.10 (NEI, 1979); para o agrupamento das linhagens foi empregada a técnica de aglomeração hierárquica da média aritmética entre pares não ponderados (UPGMA).

Para os trabalhos de hibridação foram utilizados os dois acessos mais divergentes baseados no dendrograma gerado na análise de similaridade genética. Os cruzamentos foram realizados em casas de vegetação da Embrapa 
Algodão, seguindo metodologia descrita por Santos, Godoy e Fávero (2005). As plantas foram mantidas em vasos (30 litros), contendo solo de textura francoarenosa previamente corrigido e adubado em função das necessidades da cultura. Após beneficiamento das vagens híbridas $\mathrm{F}_{1}$, as sementes foram cultivadas para obtenção da geração $F_{2}$. O plantio foi feito na Estação Experimental de Carpina, da UFRPE, em fileiras individuais de $5 \mathrm{~m}$ intercaladas com os dois parentais que funcionaram como testemunhas. Cada fileira funcionou como uma unidade experimental, representativa de cada progenie, da qual foram coletados os dados agronômicos. As plantas foram espaçadas de $0,70 \mathrm{~m}$ x 0,30 $\mathrm{m}$. O delineamento adotado foi de blocos ao acaso, onde cada planta foi considerada uma unidade de observação.

Seis descritores agronômicos foram adotados para estimar a variabilidade nas progênies $\mathrm{F}_{2-3}$, quer sejam: altura da planta, início da floração, peso de 100 vagens, peso de 100 sementes, número de vagens e de sementes por planta. Os descritores foram mensurados na colheita de cada progênie com exceção do início de floração que foi registrado quando o evento ocorreu em cada material. Nos genitores, os descritores foram tomados a partir da média de 15 plantas selecionadas ao acaso em cada repetição.

\section{RESULTADOS E DISCUSSÃO}

Dos dez primers utilizados, apenas UBC-815 e UBC-858 foram de menor contribuição, gerando apenas 15 e $22 \%$ de bandas polimórficas; os demais geraram mais de $60 \%$ de polimorfismo. Em termos de número de bandas, os mais responsivos foram UBC-818 e UBC-842, que contribuíram para maior discriminação dos acessos, gerando taxa de polimorfismo de 64 e $83 \%$, respectivamente (Tabela 3). Na Figura 1, percebe-se que as bandas mais ativas situaram-se entre 1 e $3 \mathrm{~kb}$. Apesar da grande contribuição desses dois primers, o UCB-818 foi mais expressivo em termos de separação intraespecífica dos acessos em nível molecular. Em plantas que tem alta tendência a uniformidade genética, como várias leguminosas herbáceas, o uso de primers ricos em AC ou AG adotados neste trabalho são aconselhados devido apresentarem maior contribuição aos estudos de divergência genética.

O dendrograma gerado pelo programa NTSYSPC 2.10 (ROHLF, 2000) a partir dos coeficientes de similaridade permitiu a formação de três grupos entre os genótipos avaliados (Figura 2). $\mathrm{O}$ grupo 1 aglomerou cinco genótipos, entre eles as cultivares paulista IAC Caiapó e norte americana Florunner, ambas rasteiras de ciclo longo, que contém em seu genoma genes oriundos de cultivares eretas, do grupo botânico Spanish (A. hypogaea sp.
Tabela 3 - Relação dos primers utilizados, número de bandas (NB), bandas monomórficas (NBM) e taxa de polimorfismo (TP) nos genótipos intraespecíficos de amendoim

\begin{tabular}{lccc}
\hline Primers & NB & NBM & TP $(\%)$ \\
\hline UCB-812 & 10 & 3 & 70 \\
UCB-816 & 9 & 3 & 67 \\
UCB-817 & 9 & 3 & 67 \\
UCB-818 & 14 & 5 & 64 \\
UCB-809 & 10 & 4 & 62 \\
UCB-836 & 12 & 4 & 67 \\
UCB-842 & 12 & 2 & 83 \\
UCB-847 & 9 & 3 & 67 \\
UCB-815 & 4 & 3 & 15 \\
UCB-858 & 9 & 7 & 22 \\
\hline
\end{tabular}

Figura 1 - Padrão de bandas obtido com os primers ISSR UBC-818 (A) e UBC-842 (B) em gel agarose $(0,8 \%)$, corado com Syber Green (Invitrogen). M- Marcador Ladder $1 \mathrm{~Kb}$. 1LGoPE-06, 2- CNPA 271 AM, 3- BRS Havana, 4- BR 1, 5CNPA 283 AM, 6- LViPE-06, 7- CNPA 270 AM, 8- CNPA 280 AM, 9- IAC Caiapó, 10- Florunner, 11- L 7 Bege

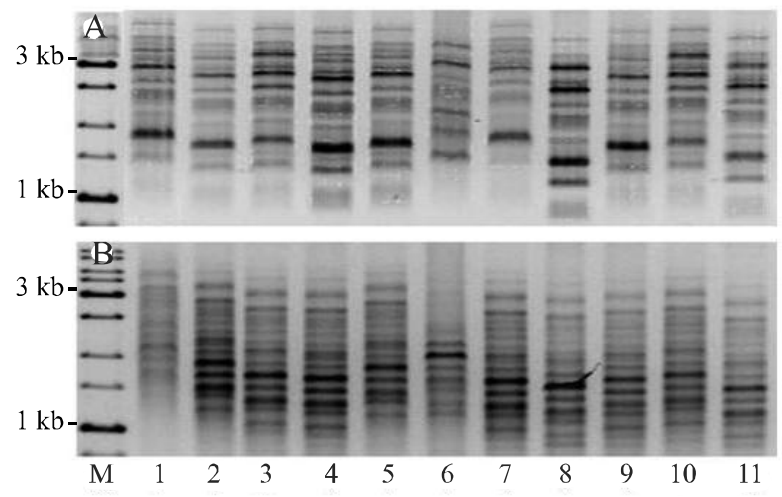

vulgaris) (GODOY et al., 1999; HENNING; ALLISON; TRIPP, 1982). Os outros genótipos foram as linhagens eretas CNPA 280 AM, CNPA 283 AM e CNPA 271 $\mathrm{AM}$, geradas por meio de cruzamento entre as cultivares Florunner e as argentinas Manfredi 407 e Manfredi 424 (GOMES et al., 2007). Em comum, os genótipos deste grupo tem ciclo acima de 115 dias, teor de óleo superior a $47 \%$ e vagens contendo 2 sementes médias a grandes, de coloração creme, com exceção da CNPA 271 AM que são vermelhas (GOMES et al., 2007).

O segundo grupo aglomerou os genótipos mais precoces, representado pelas cultivares BR 1, BRS Havana e as linhagens avançadas CNPA 270 AM e L 7 Bege. Em 
Figura 2 - Dendrograma gerado pelo programa NTSYS-PC 2.10 pelo método de clusterização UPGMA baseado nos padrões de bandas geradas via ISSR a partir de genótipos intraespecíficos de amendoim

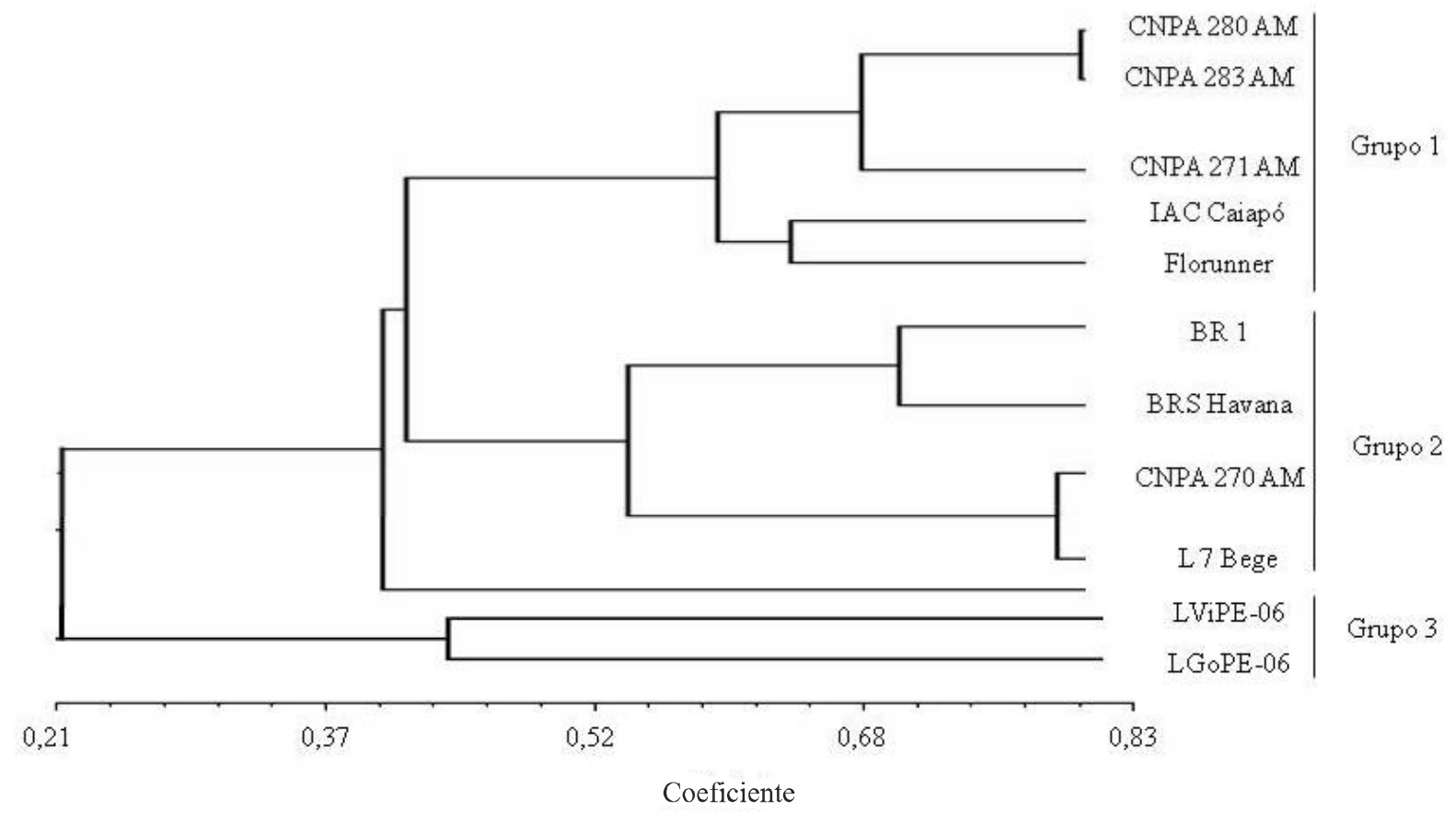

comum, todos os genótipos são de porte ereto, tem ciclo médio de 90 dias e possuem teor de óleo abaixo de $47 \%$ (GOMES et al., 2007; SANTOS; GODOY; FÁVERO, 2005). Entre os demais, a BR 1 é a mais indicada para a região Nordeste por ser mais precoce (87 dias), ter alta tolerância às condições de estresse hídrico e estabilidade para produção de grãos (GOMES et al., 2007; NOGUEIRA; SANTOS, 2000; SANTOS et al., 2010).

O grupo 3 foi representado pelos genótipos rasteiros LGoPE-06 e LViPE-06, conhecidos como "tipo cavalo". Trata-se de materiais tardios, de elevada produtividade de grãos, vagens grandes e sementes extra-longas com teor de óleo acima de 50\%. Ademais, são sensíveis a manejos em ambientes com deficiência hídrica, mas são muito tolerantes a doenças de folhagens (PEREIRA, 2010). Diferem entre si pela dormência nas sementes, presente em LGoPE-06.

Em função dos resultados apresentados no dendrograma, foramescolhidos para os trabalhos de hibridação os genótipos mais divergentes considerando-se as diferenças registradas nos seguintes atributos: hábito de crescimento (rasteiro x ereto), ciclo (tardio x precoce), adaptação a ambientes semiáridos (tolerância x sensibilidade), além da agregação de fatores agronômicos como tolerância a doenças de folhagens e produtividade de grãos e óleo, sendo selecionadas a cultivar BR 1 e a linhagem LViPE-06, respectivamente dos grupos 2 e 3.

Após a obtenção da geração $F_{1}$, procedeu-se uma análise prévia da variabilidade adquirida nas plantas tomando-se como base os fenótipos exibidos nas bandas por meio dos primers ISSR que apresentaram mais de $60 \%$ de polimorfismo. Observa-se na Figura 3 que a maioria das bandas vistas nas plantas $F_{1}$ foram herdadas da BR 1 (setas com linha cheia) e que apenas duas bandas presentes nos genitores não foram detectadas nas plantas $\mathrm{F}_{1}$ baseando-se nos primers utilizados (setas com linha pontilhada). Esse fato pode estar relacionado ao alto nível de homozigosidade da BR 1, associado à grande expressividade da maioria dos caracteres genéticos deste progenitor que foram passados, geneticamente, para os descendentes.

Após obtenção das sementes $\mathrm{F}_{1-2}$, procedeu-se o plantio para avaliação da progênie $\mathrm{F}_{2}$ em campo, baseando-se em descritores agronômicos. Com base nos dados obtidos, verificou-se ampla variabilidade genética entre os indivíduos, sendo esta contributiva para os processos de seleção, considerando-se a significância das médias e das variâncias na geração $\mathrm{F}_{2}$, em relação aos genitores (Tabela 4 ).

Esse resultado permite inferir que há genes distintos nos genitores, baseando-se na segregação transgressiva da progênie $F_{2}$, cuja população se constitui de grande utilidade para avançar no progresso do melhoramento genético do amendoim. De acordo com Gregory (1967), quando a variância é modificada na população segregante, pode ser aceita a hipótese de mais de um gene controlando o caráter por determinar maior número de classes na geração $\mathrm{F}_{2}$ em relação aos genitores. 
Figura 3 - Padrão fenotípico das bandas herdadas nas plantas $\mathrm{F}_{1}$ oriundas do cruzamento entre a BR 1 e a LViPE-06. Primers ISSR 809 (A), 818 (B), 836 (C), 842 (D), 816 (E) e 812 (F). Gel de agarose (0,8\%) corado com Syber Green (Invitrogen)

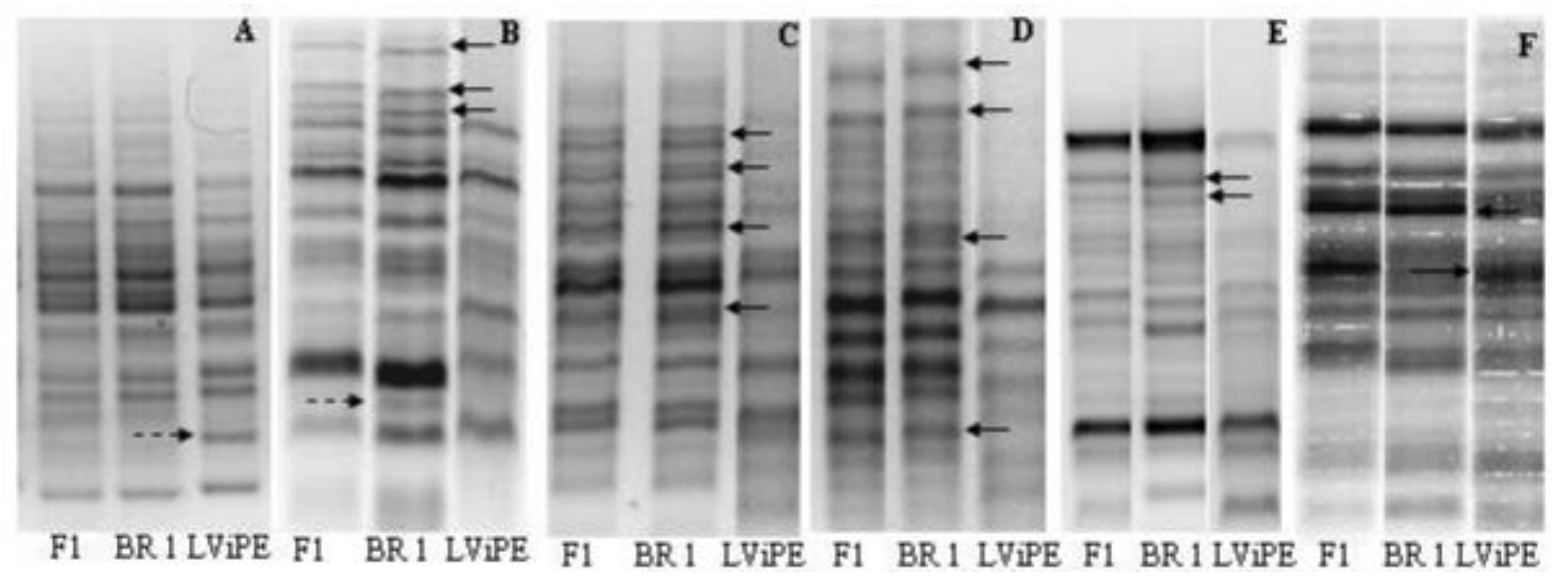

Tabela 4 - Média, variância e desvio padrão dos descritores agronômicos dos genitores e da geração segregante $F_{2}$ oriundas do cruzamento entre BR 1 e LViPE-06. Campina Grande, PB, 2010

\begin{tabular}{|c|c|c|c|c|c|}
\hline Descritor & & Número de plantas & Média & Variância & Desvio padrão \\
\hline \multirow{3}{*}{$\mathrm{AHP}(\mathrm{cm})$} & BR 1 & 15 & 40 & 34 & 5,8 \\
\hline & LViPE-06 & 15 & 16 & 1,07 & 1,03 \\
\hline & $\mathrm{F} 2$ & 225 & $20 *$ & $61 *$ & 7,8 \\
\hline \multirow{3}{*}{ IF (dae) } & BR 1 & 15 & 22 & 2,14 & 1,46 \\
\hline & LViPE-06 & 15 & 35 & 1,57 & 1,25 \\
\hline & $\mathrm{F} 2$ & 225 & $28 *$ & $35^{*}$ & 5,9 \\
\hline \multirow{3}{*}{$\mathrm{Vg} / \mathrm{pl}(\mathrm{No})$} & BR 1 & 15 & 27 & 52 & 7,2 \\
\hline & LViPE-06 & 15 & 41 & 13,6 & 3,7 \\
\hline & $\mathrm{F} 2$ & 225 & $35 *$ & $205^{*}$ & 14,3 \\
\hline \multirow{3}{*}{$\mathrm{St} / \mathrm{pl}(\mathrm{No})$} & BR 1 & 15 & 45 & 0,57 & 0,76 \\
\hline & LViPE-06 & 15 & 117 & 4,2 & 2,1 \\
\hline & $\mathrm{F} 2$ & 225 & $56 *$ & $258^{*}$ & 16,1 \\
\hline \multirow{3}{*}{ Peso de 100 vagens $(\mathrm{g})$} & BR 1 & 15 & 75 & 4,5 & 2,1 \\
\hline & LViPE-06 & 15 & 94 & 5,1 & 2,3 \\
\hline & $\mathrm{F} 2$ & 225 & $78 *$ & $1988 *$ & 44,6 \\
\hline \multirow{3}{*}{ Peso de 100 sementes $(\mathrm{g})$} & BR 1 & 15 & 145 & 1,07 & 1,03 \\
\hline & LViPE-06 & 15 & 223 & 3,92 & 1,98 \\
\hline & $\mathrm{F} 2$ & 225 & $148^{*}$ & $2069 *$ & 45,5 \\
\hline
\end{tabular}

AHP: altura da haste principal; IF: início da floração; dae: dias após a emergência; Vg/pl: número de vagens por planta; St/pl: número de sementes por planta. *significativo a 5\% de probabilidade pelo teste t para as médias e pelo teste $\mathrm{F}$ para as variâncias em relação à testemunha

A amplitude (formação de classes) dos descritores avaliados encontra-se na Figura 4. Para melhor representação da progênie $\mathrm{F}_{2}$, constituiu-se, ao acaso, 15 grupos de plantas, cada um composto de 15 progênies, de onde se computou a média de cada descritor. Observase que em todos os descritores avaliados a amplitude das médias encontradas na progênie $F_{2}$ foi larga, permitindo ampliar a base genética das linhagens a serem 
Figura 4 - Distribuição de frequência dos descritores agronômicos da BR 1 (linha pontilhada), LViPE-06 (linha tracejada) e das progênies $F_{2}$ (linha cheia)
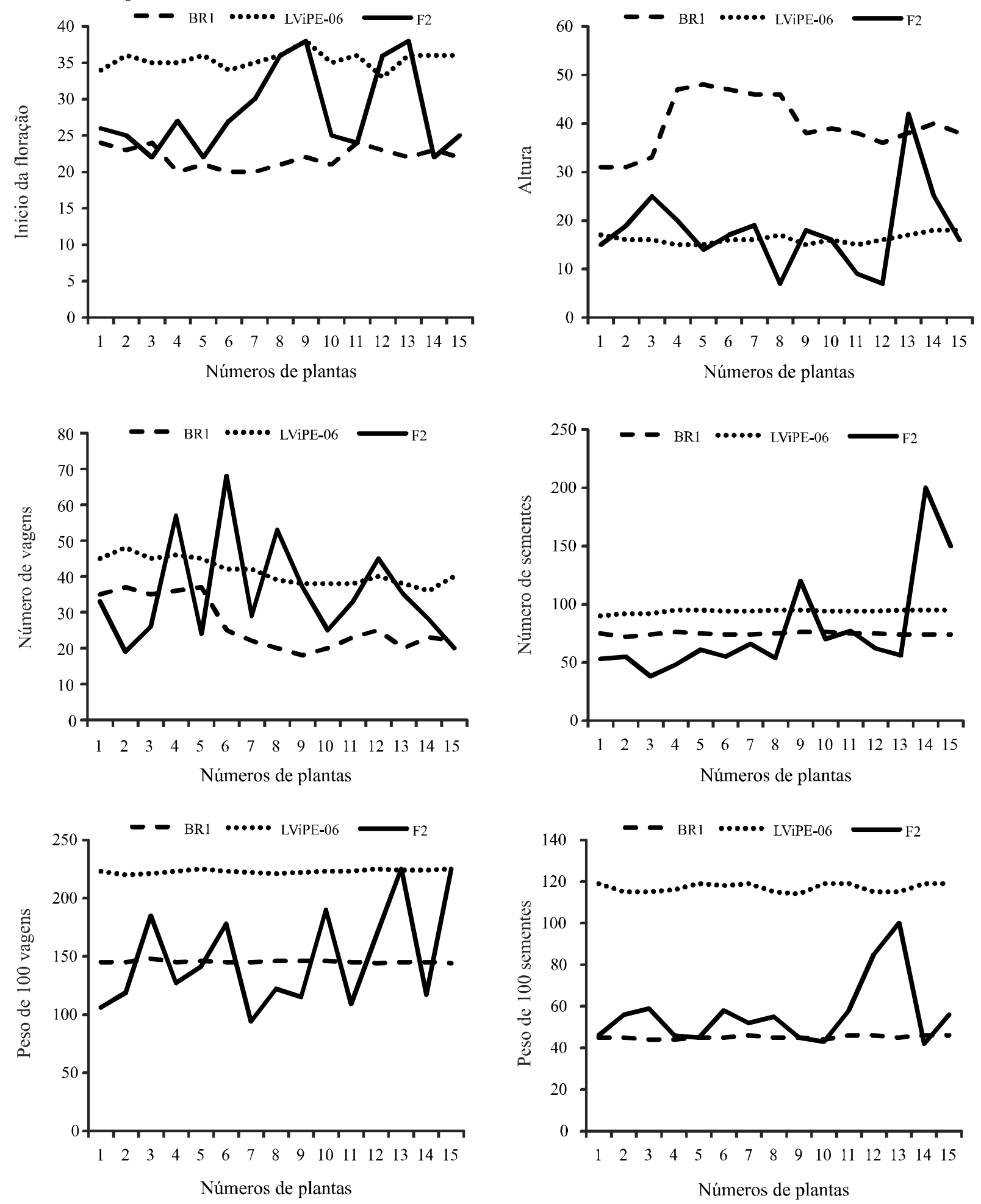

selecionadas em gerações posteriores. Entre os descritores que apresentaram maior lastro de amplitude citam-se peso de vagens (94-225 g), peso de sementes (42-100 g),

número de vagens (19-68) e número de sementes (38200). Tais descritores podem fornecer contribuição mais expressiva nos processos de seleção no melhoramento 
do amendoim. Em trabalhos sobre coeficiente de trilha utilizando descritores agronômicos de amendoim, Santos, Carvalho e Santos (2000), citam que as correlações entre produção de vagens e sementes são positivas e de alta magnitude. Segundo eles, o melhorista interessado em elevar a produção de sementes deveria aumentar a pressão de seleção sobre o rendimento em vagens, mantendo sob controle as demais variáveis, que podem ter influência indireta sobre a produção.

\section{CONCLUSÕES}

1.Com base nos resultados deste trabalho, foi possível confirmar a contribuição das ferramentas moleculares como auxiliar nos trabalhos de seleção, no melhoramento genético. O melhorista, contudo, deve fazer uma seleção prévia dos primers mais responsivos em termos de polimorfismo, o que resultará em maior confiabilidade nos resultados apresentados dos marcadores utilizados;

2. A população gerada neste trabalho, por meio da indicação dos resultados obtidos via ISSR, é de alta variabilidade, confirmando a assertiva no uso da técnica para geração de populações divergentes e posterior sucesso nos trabalhos de melhoramento.

\section{AGRADECIMENTOS}

Ao MCT/CNPq/MEC/CAPES/CT-AGRO/CTIDRO/FAPS/EMBRAPA, por meio da REPENSA (Redes Nacionais de Pesquisa em Agrobiodiversidade e Sustentabilidade Agropecuária) pelo suporte financeiro do plano de ação associado a presente pesquisa (CNPqProcesso.562392/2010-6).

\section{REFERÊNCIAS}

BARAKAT, M. N.; EL-SHAFEI, A. M.; AL-DOSS, A. Molecular mapping of QTLs for resistance to northern corn leaf blight in maize. International journal of food, agriculture and environment, v. 08, n. 2, p. 547-552, 2010.

FOOD AND AGRICULTURE ORGANIZATION OF THE UNITED NATIONS FAOSTAT, 2010. Levantamento da produção mundial de amendoim e óleo. Disponível em: <http:// faostat.fao.org/>. Acesso em: 15 jun. 2010.

FERREIRA, M. E.; GRATTAPAGLIA, D. Introdução ao uso de marcadores moleculares em análise genética. 3. ed. Brasília: Embrapa-Cenargen, 1998. 220 p.

GODOY, I. J. et al. Amendoim. In: GODOY, I. J. et al. Oleaginosas no Estado de São Paulo: análise e diagnóstico. Campinas: DCT/SAA/CATI, 1999. p. 3-12.
GOMES, L. R. et al. Adaptabilidade e estabilidade fenotípica de genótipos de amendoim de porte ereto. Pesquisa Agropecuária Brasileira, v. 42, n. 7, p. 985-989, 2007.

GREGORY, W. C. Mutation breeding. In: FREY, K. J. Plant breeding. Ames: Iowa State University, 1967. cap. 5, p. 189-217.

HAWKINS, J. S.; PLEASANTS, J.; WENDEL, J. F. Identification of AFLP markers that discriminate between cultivated cotton and the Hawaiian island endemic, Gossypium tomentosum Nuttall ex Seeman. Genetic Resources and Crop Evolution, v. 52, n. 8, p. 1069-1078, 2005.

HENNING, R. J.; ALLISON, A. H.; TRIPP, L. D. Cultural practices. In: PATTEE, H. E.; YOUNG, C. T. (Ed.). Peanut Science and Technology. Stillwater: American Peanut Research and Education Society, 1982. chp. 5, p. 123-138.

INSTITUTO BRASILEIRO DE GEOGRAFIA E ESTATÍSTICA. Produção Agrícola. Disponível em: <http:// www.ibge.gov.br/home/estatistica/indicadores/ agropecuaria/ 1spa/lspa_201003_7.shtm>. Acesso em: 20 mar. 2013.

MENG, X.; CHEN, W. Applications of AFLP and ISSR techniques in detecting genetic diversity in the soybean brown stem rot pathogen Phialophora gregata. Mycological Research, v. 105, n. 8, p. 936-940, 2001.

NEI, M.; LI, W. H. Mathematical model for studing genetic variation in terms of restriction endonuclease. Proceedings of the National Academy of Sciences of the United States of America, v. 76, n. 10, p. 5269-5273, 1979.

NOGUEIRA, R. J. M. C.; SANTOS, R. C. Alterações fisiológicas no amendoim submetido ao estresse hídrico. Revista Brasileira de Engenharia Agrícola e Ambiental, v. 4, n. 1, p. 41-45, 2000.

PEREIRA, J. W. L. Respostas fisiológica e agronômica de genótipos de amendoim sob condição de estresse hídrico. 2010. 64 f. Dissertação (Mestrado em Agronomia) - Universidade Federal Rural de Pernambuco, Recife, 2010.

RODRIGUES, T. B. et al. QTLs identification in common bean through SSR markers affected by natural selection. Ciência e Agrotecnologia, v. 31, n. 5, p. 1351-1357, 2007.

ROHLF, F. J. NTSYS-PC: numerical taxonomy and multivariate analysis system, version 2.1. New York: Exeter Software, 2000.

SANTOS, M. M. S.; SANTOS, R. C. Validação de um protocolo rápido para extração de DNA vegetal. In: JORNADA DE ENSINO, PESQUISA E EXTENSÃO DA UFRPE, 8., 2008, Pernambuco. Anais... Recife: UFRPE, 2008.

SANTOS, R. C. et al. Produtividade de linhagens avançadas de amendoim em condições de sequeiro no Nordeste brasileiro. Revista Brasileira de Engenharia Agrícola e Ambiental, v. 14, n. 6, p. 589-593, 2010.

SANTOS, R. C.; CARVALHO, L. P.; SANTOS, V. F. Análise de coeficiente de trilha para os componentes de produção em amendoim. Ciência e Agrotecnologia, v. 24, n. 1, p. 13-16, 2000 . 
SANTOS, R. C.; GODOY, I. J.; FÁVERO, A. P. Melhoramento do amendoim. In: SANTOS, R. C. O agronegócio do amendoim no Brasil. Campina Grande: Embrapa Algodão, 2005. cap. 6, p.123-192.

SNEATH, P. H. A.; SOKAL, R. R. Numerical taxonomy. San Francisco, W.F: Freeman, 1973. 573 p.
UNITED STATES DEPARTMENT OF AGRICULTURE. Foreign Agricultural Service. Disponível em: <http://www.fas. usda.gov/psdonline/psdreport>. Acesso em: 14 jun. 2010.

VALLS, J. F. M. Recursos genéticos do gênero Arachis. In: SANTOS, R. C. O Agronegócio do Amendoim no Brasil. Campina Grande: Embrapa Algodão, 2005. cap. 2, p. 45-69. 